Ilona Marta PIOTROWSKA-MICHALAK

Akademia Sztuki Wojennej ${ }^{1}$

Wydzial Bezpieczeństwa Narodowego

ilonamarta.piotrowska@wp.pl

ORCID 0000-0002-4736-5694

https://doi.org/10.34739/dsd.2020.02.13

\title{
ZADANIA OBRONNE REALIZOWANE PRZEZ SAMORZĄDY TERYTORIALNE W POLSCE
}

\begin{abstract}
ABSTRAKT: Niniejszy artykuł stanowi próbę identyfikacji zadań obronnych wykonywanych na poszczególnych szczeblach samorządu terytorialnego. Zadania obronne realizowane są w ramach Systemu Obronnego Państwa, który jest podsystemem Systemu Bezpieczeństwa Narodowego. Wobec tego w artykule wskazano usytuowanie Systemu Obronnego w Systemie Bezpieczeństwa Narodowego, struktury Systemu Bezpieczeństwa Narodowego oraz misję poszczególnych jego podsystemów. Przedstawiono również funkcjonowanie samorządu terytorialnego w Polsce i dokonano próby identyfikacji zadań obronnych realizowane przez samorządy terytorialne. Przedmiotem badań niniejszego artykułu są zadania obronne realizowane przez samorządy terytorialne $\mathrm{w}$ Polsce, celem natomiast próba identyfikacji zadań obronnych wykonywanych na poszczególnych szczeblach samorządu terytorialnego. W pracy wykorzystano teoretyczne metody badawcze: analizę, syntezę, abstrahowanie oraz wnioskowanie.
\end{abstract}

SŁoWA KLUCZOWE: samorząd terytorialny, zadania obronne, System Obronny Państwa

\section{DEFENCE TASKS IMPLEMENTED BY TERRITORIAL SELF-GOVERNMENT IN POLAND}

\begin{abstract}
This article is an attempt to identify defensive tasks performed at individual levels of territorial self-government in Poland. Defense tasks are implemented within the State Defense System, which is a subsystem of the National Security System (NSS). Therefore, the article indicates the location of the Defense System in the National Security System, the structure of NSS and the mission of its individual subsystems. The author also presents the functioning of territorial selfgovernment in Poland and specifies tasks implemented by territorial self-government. The subject of the research are defense tasks implemented by local governments in Poland, and the aim is an attempt to identify defense tasks performed at individual levels of local government. The following theoretical research methods were used: analysis, synthesis, abstraction and inference.
\end{abstract}

KEYWORDS: territorial self-government, defence tasks, State Defense System

${ }^{1}$ War Studies Academy; Poland 


\section{WPROWADZENIE}

Aby istnieć, państwo jako forma organizacji społeczeństwa musi spełniać szereg warunków, takich jak posiadanie określonego terytorium (oddzielonego od innych państw granicą), ludności (identyfikującej się z tworem państwowym, posiadającej wspólną religię, kulturę, język), struktur karnych, suwerennej władzy oraz zdolności do wchodzenia w relacje międzynarodowe. Państwo winno posiadać skuteczny system obronny przed potencjalną agresją nieprzyjaciela, aby zapewnić niepodległość i suwerenność państwa oraz integralność terytorialną, a także podstawowe wolności i umacniać demokratyczny porządek polityczny.

W Polsce zagadnienia dotyczące obronności zostały uregulowane w wielu aktach prawnych. Zarówno administracji rządowej i samorządowej, jak i przedsiębiorcom narzuca się wiele zadań, których celem jest zapewnienie bezpieczeństwa.

Przedmiotem podjętych badań są zadania obronne realizowane przez samorządy terytorialne w Polsce, natomiast celem niniejszego artykułu jest próba identyfikacji zadań obronnych wykonywanych na poszczególnych szczeblach samorządu terytorialnego. Głównym problemem badawczym jest pytanie: Jakie zadania obronne realizują samorządy terytorialne w Polsce? Pytanie to wymaga odpowiedzi na szereg pytań szczegółowych: (1) Jakie jest usytuowanie Systemu Obronnego Państwa w Systemie Bezpieczeństwa Narodowego? (2) Jakie są rodzaje zadań obronnych w Polsce? (3) Jak zorganizowany jest samorząd terytorialny w Polsce? (4) Jakie zadnia obronne przypisuje się samorządowi terytorialnemu na poszczególnych szczeblach? Próbę rozwiązania powyższych problemów podjęto opierając się o przegląd literatury oraz aktów prawnych przy zastosowaniu teoretycznych metod badawczych takich jak: analiza, synteza, abstrahowanie oraz wnioskowanie.

Zadania obronne realizowane są w ramach Systemu Obronnego Państwa, który to jest podsystemem Systemu Bezpieczeństwa Narodowego. Wobec tego zasadnym jest wskazanie usytuowania Systemu Obronnego w Systemie Bezpieczeństwa Narodowego, struktury Systemu Bezpieczeństwa Narodowego i misji poszczególnych jego podsystemów, co zostanie uczynione w pierwszej części pracy. Następnie dokonana zostanie próba identyfikacji zadań obronnych. Aby wskazać zadania obronne realizowane przez samorządy terytorialne należy uprzednio wyjaśnić istotę działalności samorządu terytorialnego w Polsce. Kolejna część podjętych rozważań dotyczyć będzie zadań obronnych oraz zakresu przedmiotowego przygotowań obronnych państwa realizowanych przez samorządy terytorialne. Dywagacje zakończone zostaną podsumowaniem.

\section{SYSTEM OBRONNY PAŃSTWA W SYSTEMIE BEZPIECZEŃSTWA NARODOWEGO}

W celu właściwego zrozumienia miejsca Systemu Obronności Państwa konieczne jest wskazanie usytuowania tegoż systemu w Systemie Bezpieczeństwa Narodowego oraz krótki opis funkcjonowania Systemu Bezpieczeństwa Narodowego w naszym kraju.

System Bezpieczeństwa Narodowego definiowany jest jako „całość sił (podmiotów), środków i zasobów przeznaczonych przez państwo do realizacji zadań w dziedzinie bezpieczeństwa, odpowiednio do tych zadań zorganizowana (w podsystemy i ogniwa), 
utrzymywana i przygotowywana. Składa się z podsystemu (systemu) kierowania i szeregu podsystemów (systemów) wykonawczych"”2.

System bezpieczeństwa narodowego jest przygotowany do skutecznego działania w trzech różnych stanach:

- normalnym (podejmuje się wówczas działania rutynowe mające na celu utrzymanie tego stanu),

- kryzysowym, gdy dotychczasowy proces rozwoju załamuje się, a funkcjonowanie podmiotu zostaje zakłócone (wówczas działania rutynowe nie wystarczą, dochodzi do utraty kontroli, zakłócony zostaje proces decyzyjny, a wydarzenia wyprzedzają reagowanie),

- nadzwyczajnym, gdy dochodzi do krachu, upadku, likwidacji czy innej zmiany systemowej; ze stanem tym mamy do czynienia wówczas, gdy nie uda się zlikwidować stanu kryzysowego i powrócić do normalnego; ostatecznie stan nadzwyczajny może przerodzić się w konflikt zbrojny ${ }^{3}$.

Zgodnie z uniwersalnym modelem systemu bezpieczeństwa narodowego, zamieszczonym na Rysunku 1, wyróżnić należy podsystem kierowania oraz podsystemy wykonawcze. Istotą działalności organów kierowania jest „zapewnienie ciągłości podejmowania decyzji i koordynacji działań dla utrzymania i przywracania bezpieczeństwa narodowego we wszystkich możliwych stanach i okolicznościach funkcjonowania państwa. Struktura systemu kierowania bezpieczeństwem narodowym powinna być zgodna z uniwersalnym modelem kierowania, który obejmuje trzy elementy składowe: decydenta, kolegialny organ doradczy oraz stały (etatowy) organ sztabowy"4.

W Polsce funkcja decydenta jest kolegialna, pełnią ją Prezydent RP oraz Rada Ministrów, przy czym Prezydent dysponuje organem doradczym, którym jest Rada Bezpieczeństwa Narodowego, oraz sztabowym w postaci Biura Bezpieczeństwa Narodowego, podczas gdy Rada Ministrów takich organów nie posiada. Za najbliższe im odpowiedniki można uznać Rządowy Zespół Zarządzania Kryzysowego i Rządowe Centrum Bezpieczeństwa. Kompetencje tychże organów ograniczają się jednak do spraw związanych z zarządzaniem kryzysowym, nie obejmując w całości problemów bezpieczeństwa narodowego 5 .

\footnotetext{
2 (MINI)SŁOWNIK BBN: Propozycje nowych terminów z dziedziny bezpieczeństwa, https://www.bbn.gov.pl/pl/ bezpieczenstwo-narodowe/minislownik-bbn-propozy/6035,MINISLOWNIK-BBN-Propozycje-nowychterminow-z-dziedziny-bezpieczenstwa.html (27.05.2019)

${ }^{3}$ Vide: Biała Księga Bezpieczeństwa Narodowego Rzeczypospolitej Polskiej, Warszawa 2013, s. 194.

${ }^{4}$ Ibidem, s. 195.

${ }^{5}$ Ibidem.
} 


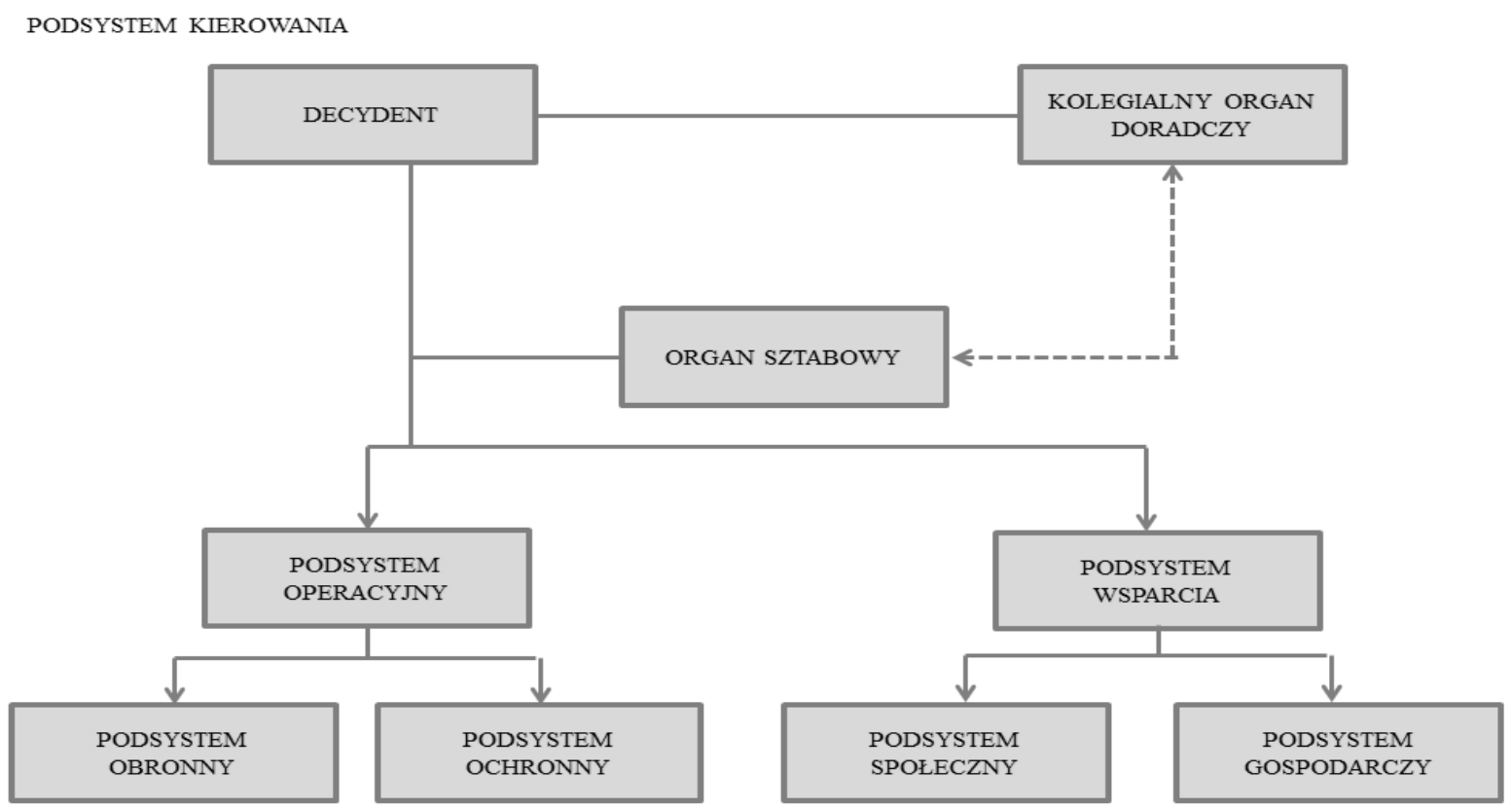

PODSYSTEM WYKONAWCZY

Rysunek 3. Uniwersalny model systemu bezpieczeństwa narodowego

Źródło: M. Kuliczkowski, Pozamilitarne przygotowanie obronne w Polsce: próba systematyzacji procesualnych oraz funkcjonalnych aspektów przygotowań, Warszawa 2016, s. 34.

W ramach podsystemu wykonawczego wyróżnia się podsystemy operacyjne (obronny i ochronny) oraz wsparcia (społeczny i gospodarczy).

Podsystem ochronny związany jest z działalnością państwa realizowaną przez takie organy i instytucje jak: wymiar sprawiedliwości, służby specjalne, instytucje zwalczania terroryzmu i przeciwdziałania ekstremizmowi politycznemu, instytucje właściwe do spraw cyberbezpieczeństwa, instytucje ochrony informacji niejawnych, służby i straże porządku publicznego, służby ratownictwa i ochrony ludności, służby graniczne oraz inne podsystemy ochronne ${ }^{6}$. Ich celem jest zapewnienie ochrony ludności w tym zapewnienie swobody korzystania z praw i wolności obywatelskich oraz zagwarantowanie bezpieczeństwa publicznego i zarządzanie kryzysowe.

Podsystem społeczny związany jest z działalnością na rzecz ochrony dziedzictwa narodowego, instytucji edukacji dla bezpieczeństwa oraz innymi instytucjami naukowo-badawczymi i badawczorozwojowymi, które dotyczą sfery bezpieczeństwa, a także z przeciwdziałaniem zagrożeniom demograficznym. Ponadto system ten obejmuje również działalność służby zdrowia oraz dotyka problemów związanych ze środkami masowego przekazu, które są podstawowym narzędziem obiegu informacji ${ }^{7}$.

\footnotetext{
${ }^{6}$ Ibidem, s. 209-224.
}

${ }^{7}$ Ibidem, s. 224-230. 
Podsystem gospodarczy dotyczy działań instytucji bezpieczeństwa finansowego, podmiotów bezpieczeństwa energetycznego, instytucji bezpieczeństwa infrastruktury krytycznej, rezerw strategicznych oraz systemu ochrony środowiska ${ }^{8}$.

Wreszcie system obronny, w którego skład wchodzą: dyplomacja, Siły Zbrojne, wojskowe służby specjalne oraz przemysł obronny ${ }^{9}$. Choć Siły Zbroje są głównym podmiotem, to „nie wyczerpują $\mathrm{w}$ pełni zakresu podmiotowego tego podsystemu, a obszarem wiążącym podsystem obronny z pozostałymi podsystemami jest planowanie obronne. Wymienione ogniwa, poza Siła Zbrojnymi, tworzą pozamilitarny potencjał obronny państwa pracujący na rzecz bezpieczeństwa narodowego"10. Należy zwrócić uwagę, że choć Biała Księga Bezpieczeństwa Narodowego RP sprowadza System Obrony Państwa jedynie do rangi jednego z podsystemów wykonawczych, to Strategia Rozwoju Bezpieczeństwa Narodowego RP 2022 uznaje go jednak za zasadniczą formę organizacji i funkcjonowania Systemu Bezpieczeństwa Narodowego ${ }^{11}$.

W ramach Systemu Obronnego Państwa należy wyróżnić trzy podsystemy: kierowania obronnością, militarny oraz niemilitarny, co zostało przedstawione na Rysunku 2. Sprawne działanie tych trzech systemów jest determinantą właściwego działania Systemu Obronnego.

Podsystem kierowania obronnością stanowi zasadniczy element podsystemu kierowania bezpieczeństwem narodowym. „Tworzą go powiązane organizacyjnie i informacyjnie organy władzy i administracji publicznej (wraz z obsługującymi urzędami i niezbędną infrastrukturą) i kierownicy jednostek organizacyjnych, które wykonują zadania związane $\mathrm{z}$ obronnością oraz organy dowodzenia Sił Zbrojnych RP, adekwatnie do ich hierarchicznego podporządkowania i prawnie określonych kompetencji. Przeznaczony jest on do zapewnienia optymalnych warunków do sprawnego podejmowania decyzji oraz ciągłego i trwałego koordynowania działań przez organy władzy i administracji publicznej wszystkich szczebli oraz organy dowodzenia Sił Zbrojnych RP zarówno w czasie pokoju, kryzysu, a przede wszystkim - wojny"12.

\footnotetext{
${ }^{8}$ Ibidem, s. 231-233.

${ }^{9}$ Ibidem, s. 201-209.

${ }^{10}$ M. Kuliczkowski, Pozamilitarne przygotowanie obronne w Polsce: próba systematyzacji procesualnych oraz funkcjonalnych aspektów przygotowań, Warszawa 2016, s. 35.

${ }^{11}$ Ibidem, s. 35-36.

${ }^{12}$ Strategia obronności Rzeczypospolitej Polskiej z dnia 23 grudnia 2009 r. - Strategia sektorowa do Strategii Bezpieczeństwa Narodowego Rzeczypospolitej Polskiej, pkt 60.
} 


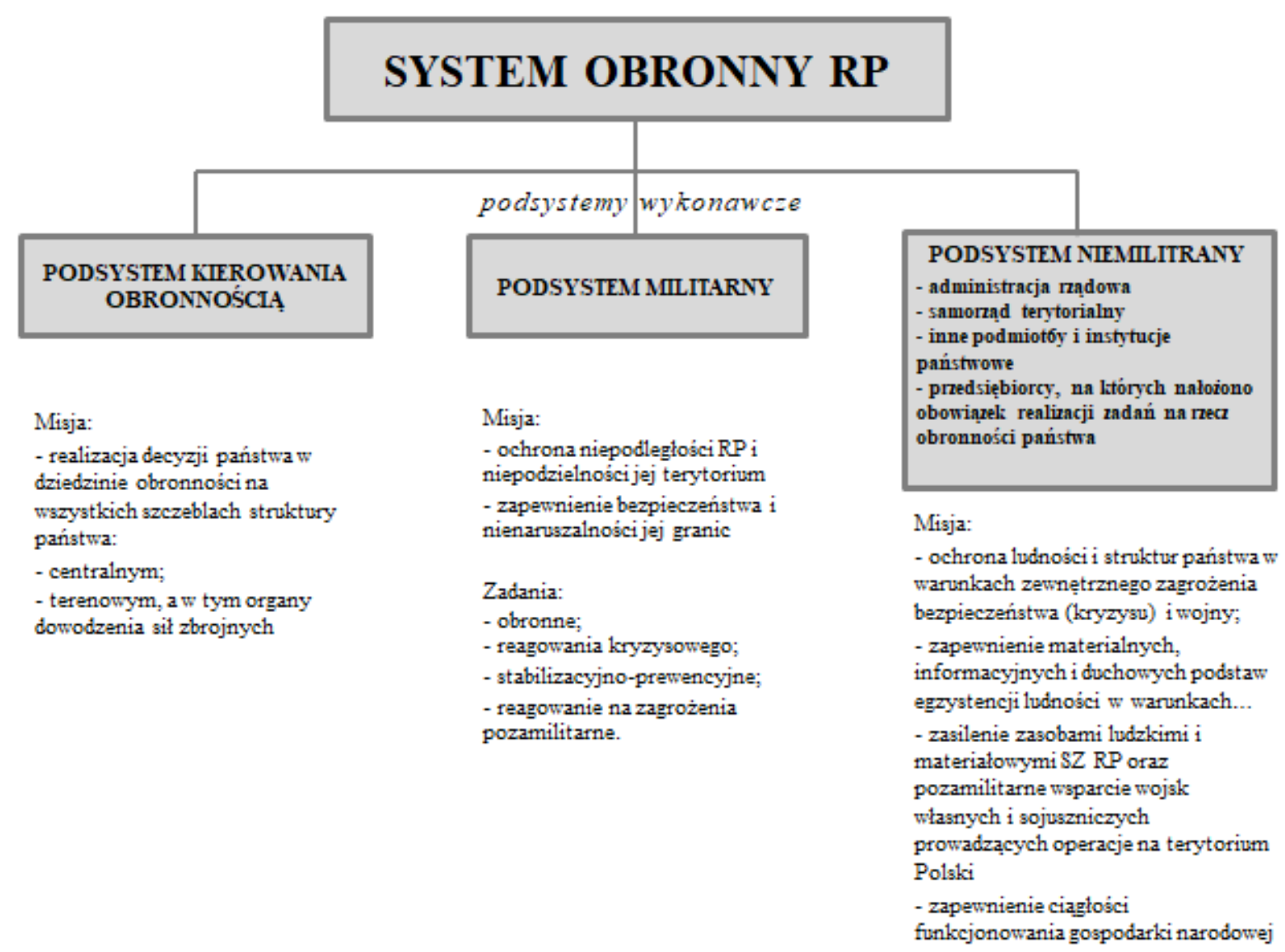

Rysunek 4. Struktura Systemu Obronnego Państwa oraz misje realizowane w jego podsystemach Źródło: W. Kitler, Organizacja bezpieczeństwa narodowego Rzeczypospolitej Polskiej: aspekty ustrojowe, prawno-administracyjne i systemowe, Torun 2018, s. 357.

Podsystem militarny tworzony jest przez Siły Zbrojne RP. Podsystem realizuje zadania zmierzające do zwiększenia potencjału Sił Zbrojnych, uzyskania wysokiej gotowości do użycia wojsk oraz przygotowania nowoczesnej infrastruktury obronnej do zadań związanych z obowiązkami państwa-gospodarza i współpracy cywilno-wojskowej ${ }^{13}$.

Administracja rządowa, samorząd terytorialny oraz inne podmioty i instytucje (w tym m.in. przedsiębiorcy) realizują zadania $\mathrm{w}$ ramach podsystemu niemilitarnego, którego celem jest ochrona struktur państwa oraz ludności w warunkach kryzysu i wojny, zapewnienie materialnych i duchowych potrzeb egzystencji ludności w obliczu zagrożenia, zasilenie w razie potrzeby zasobami ludzkimi i materialnymi Sił Zbrojnych RP oraz pozamilitarne wsparcie wojsk własnych i sojuszniczych prowadzących operacje na terytorium naszego kraju ${ }^{14}$.

Należy zwrócić uwagę, że skuteczne działanie wszystkich podsystemów Systemu Obronnego Państwa jest konieczne dla właściwego funkcjonowania całości. „Sprawne funkcjonujący System

\footnotetext{
${ }^{13}$ Vide: M. Kuliczkowski, Przygotowanie obronne państwa w systemie bezpieczeństwa narodowego - wybrane problemy, [w:] red. M. Kuliczkowski, M. Olszewski, S. Olearczyk, Administracja publiczna i przedsiębiorcy w obszarze pozamilitarnych przygotowań obronnych państwa. Wybrane zagadnienia teorii i praktyki, Warszawa 2011, s. 32.

${ }^{14}$ Vide: Ibidem.
} 
Obronny Państwa stanowi zasadniczy mechanizm zapewnienia bezpieczeństwa na wypadek

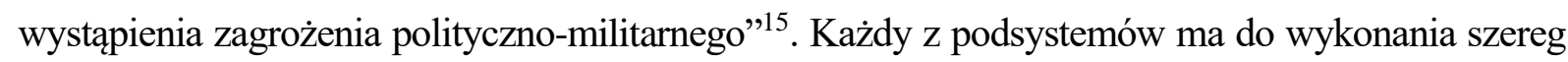
określonych zadań obronnych.

\section{IDENTYFIKACJA ZADAŃ OBRONNYCH}

Choć zadania obronne pojawiły się dość dawno, to sama definicja tego terminu była podejmowana niejednokrotnie. Za Waldemarem Kitlerem należy przyjąć, że zadania obronne to „,zęść zadań z zakresu bezpieczeństwa narodowego - to skonkretyzowane przedsięwzięcia realizowane przez organy władzy i administracji rządowej oraz inne organy i instytucje państwowe, organy samorządu terytorialnego, przedsiębiorców, organizacje pozarządowe oraz poszczególnych obywateli, obejmujące: przygotowanie państwa do sprawnego działania i przetrwania w warunkach zewnętrznego zagrożenia bezpieczeństwa państwa, kryzysu i wojny; realizację określonych przedsięwzięć operacyjnych w tych warunkach, a także usuwanie konsekwencji po usunięciu zagrożenia z przywróceniem stanu normalnego funkcjonowania państwa włącznie" ${ }^{\prime 16}$.

Klasyfikacja zadań obronnych ze względu na ich rodzaj pozwala wyróżnić zadania w sferze kierowania obronnością państwa, militarne oraz niemilitarne, co zostało przedstawione na Rysunku 3.

\footnotetext{
${ }^{15}$ M. Kuliczkowski, Pozamilitarne przygotowanie obronne..., op. cit., s. 40.

${ }^{16} \mathrm{~W}$. Kitler, Zadania obronne samorządu terytorialnego w świetle obowiazzujacych przepisów prawnych, [w:] red. W. Kitler, Zadania obronne samorzadu terytorialnego: materiat studyjny, Warszawa 2006, s. 19.
} 


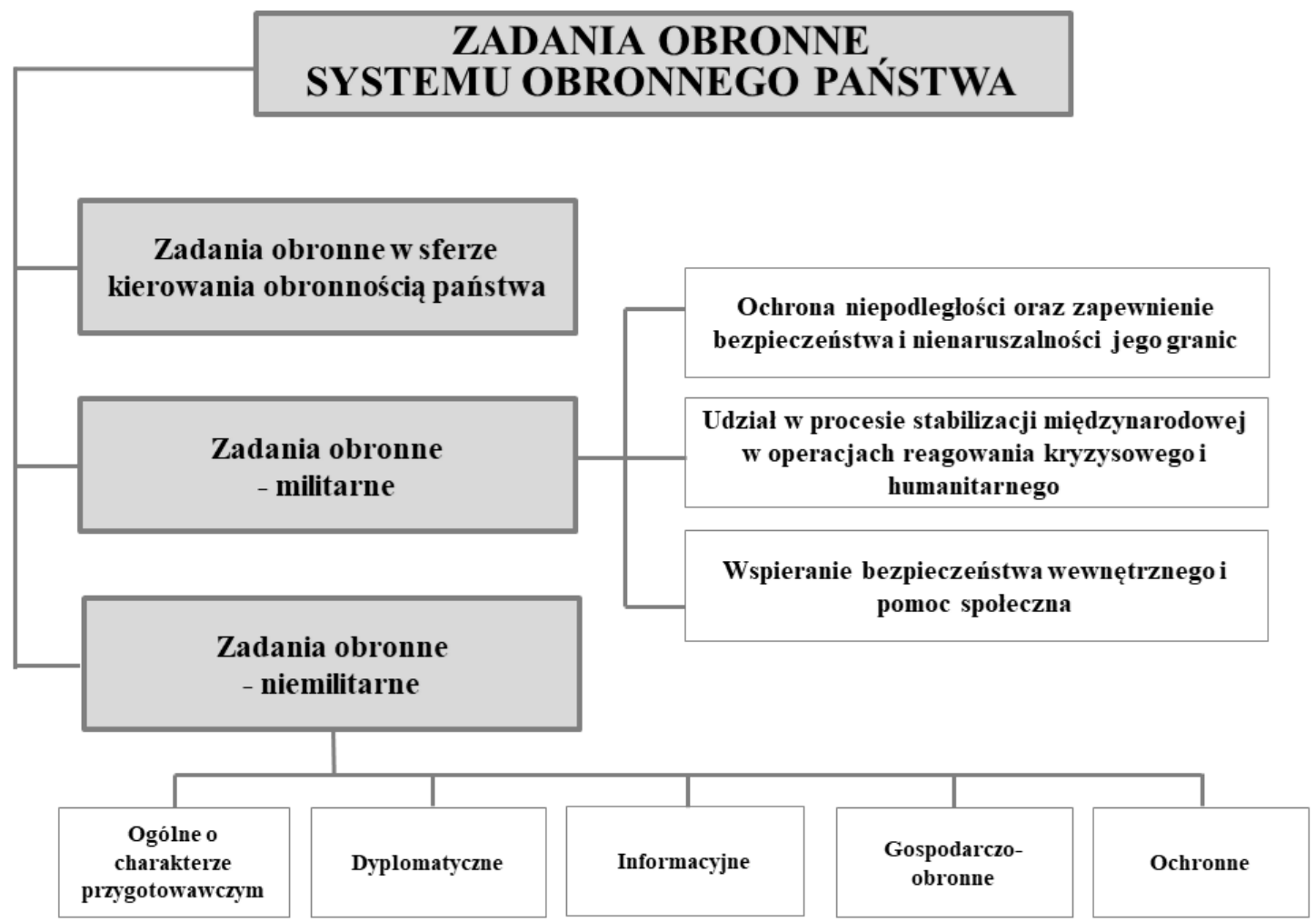

Rysunek 5. Klasyfikacja zadań obronnych Systemu Obronnego Państwa według kryterium rodzaju Źródło: M. Kuliczkowski, Przygotowanie obronne w Polsce..., op. cit., s. 55.

Zadania obronne w sferze kierowania obronnością państwa związane są z zapewnieniem odpowiednich warunków do sprawnego podejmowania decyzji, a także ciągłego koordynowania działań podejmowanych przez organy władzy i administracji publicznej na wszystkich szczeblach oraz przez organy dowodzenia Sił Zbrojnych RP w czasie pokoju, kryzysu i wojny ${ }^{17}$.

Zadania obronne - militarne realizowane są przez Siły Zbrojne RP, a ich celem jest utrzymanie gotowości do realizacji trzech rodzajów misji: zagwarantowanie obrony państwa i przeciwstawienie się agresji (zadania związane z obroną i ochroną nienaruszalności granic RP, udział w działaniach antyterrorystycznych oraz w rozwiązywaniu konfliktów regionalnych i lokalnych na obszarze odpowiedzialności NATO lub w ramach zobowiązań sojuszniczych, prowadzenie strategicznej operacji obronnej na terenie RP), udział w procesie stabilizacji sytuacji międzynarodowej oraz w operacjach reagowania kryzysowego i humanitarnego (udział w operacjach pokojowych, reagowania kryzysowego, humanitarnych realizowanych przez NATO, UE, ONZ lub inne organizacje międzynarodowe i rządowe, współpraca w zakresie budowania zaufania i bezpieczeństwa), wspieranie bezpieczeństwa wewnętrznego i pomoc społeczna (monitorowanie i ochrona przestrzeni powietrznej, lądowej, wód terytorialnych, prowadzenie działalności rozpoznawczej i wywiadowczej, monitorowanie skażeń chemicznych, biologicznych, promieniotwórczych, oczyszczanie terenu z materiałów wybuchowych i przedmiotów

${ }^{17}$ Vide: M. Kuliczkowski, Pozamilitarne przygotowanie obronne..., op. cit., s. 56. 
niebezpiecznych pochodzenia wojskowego, prowadzenie działań poszukiwawczo -ratowniczych, pomoc $\mathrm{w}$ reagowaniu na zagrożenia władzom państwowym, administracji publicznej oraz społeczeństwu $)^{18}$.

Z punktu widzenia realizowania zadań obronnych przez samorządy terytorialne, istotne są zadania niemilitarne. „Celem zadań ogólnych o charakterze przygotowawczym jest stworzenie warunków organizacyjnych do funkcjonowania w określonej sytuacji planistycznej i realizacji zadań operacyjnych. Zadania dyplomatyczne mając na celu minimalizowanie ryzyka zagrożenia podstawowych interesów narodowych, wsparcie dyplomatyczne w czasie konfliktu zbrojnego i jego wygaszania. Zadania informacyjne służą ochronie i propagowaniu polskich interesów, informacyjnemu osłabieniu przeciwnika, umacnianiu woli, morale, determinacji obronnej i wytrwałości społeczeństwa"19. Zadania gospodarczo-obronne mają na celu zapewnienie podstaw materialnych takich jak: „utrzymanie mocy produkcyjnych i remontowych niezbędnych do realizacji zadań wynikających z Programu Mobilizacji Gospodarki (PMG); przygotowanie do produkcji i usług oraz realizacji zadań ujętych w PMG; tworzenie i utrzymanie rezerw; przygotowanie transportu na potrzeby obronne; przygotowanie do działania w warunkach ograniczonych dostaw; uruchomienie świadczeń osobistych i rzeczowych; utrzymywanie rezerw strategicznych; przyspieszenie realizacji inwestycji o znaczeniu strategicznym; wprowadzenie ograniczeń w komunikacji, łączności; odtworzenie zniszczonej infrastruktury; zapewnienie zaopatrywania formacji obrony cywilnej wsprzęt, materiały i środki ochrony; monitorowanie potencjału ekonomicznego w zakresie przemysłu, rolnictwa, łączności, transportu, energetyki, leśnictwa"20. Zadania ochronne mają zapewnić potrzeby bytowe ludności oraz sprawne funkcjonowanie państwa.

Samorządy terytorialne mają swój udział w wykonywaniu poszczególnych zadań obronnych. Zadania wykonywane na poszczególnych szczeblach związane są z organizacją samorządu terytorialnego w Polsce.

\section{Organizacja SAMorządu Terytorialnego W POLSCE}

„Samorząd terytorialny jest opartą na przepisach ustawy zdecentralizowaną administracją państwową, wykonywaną przez lokalne organy, niepodległe hierarchicznie innym organom i samodzielne w granicach ustawy i ogólnego porządku prawnego"21. Podstawą prawną działalności samorządu terytorialnego w Polsce jest Konstytucja Rzeczypospolitej Polskiej.

W latach 90. ubiegłego wieku w administracji publicznej dokonano zasadniczych przekształceń, których celem była decentralizacja władzy publicznej. Od 1 stycznia 1999 r. wprowadzony został trójstopniowy podział państwa na województwa, powiaty (w tym miasta na

\footnotetext{
${ }^{18}$ Ibidem.

${ }^{19}$ W. Kitler, Zadania obronne samorzadu..., op. cit., s. 19-20.

${ }^{20}$ M. Kuliczkowski, Pozamilitarne przygotowanie..., op. cit., s. 74.

${ }^{21}$ J. Panejko, Geneza i podstawy samorzadu europejskiego, Wilno 1934., s. 111.; Vide: K. Byjoch, J. Sulimierski,

J.P. Tarno, Samorzą terytorialny po reformie ustrojowej państwa, Warszawa 2000, s. 14.
} 
prawach powiatu) i gminy. Obecnie Rzeczpospolita Polska podzielona jest na 16 województw, 380 powiatów (w tym 314 powiatów i 66 miast na prawach powiatu) oraz 2477 gmin.

Podstawową jednostką samorządu terytorialnego jest gmina, której organem uchwałodawczym jest rada gminy, wykonawczym natomiast wójt, burmistrz lub prezydent miasta. Rada gminy jako organ stanowiący i kontrolny może rozstrzygać wszelkie kwestie pozostające $\mathrm{w}$ zakresie działania gminy, które nie są zastrzeżone dla referendum ${ }^{22}$. Radę wybierają mieszkańcy w wyborach powszechnych, równych, bezpośrednich i w głosowaniu tajnym. Kadencja rady trwa 5 lat. Liczba radnych zależy od ilości osób zamieszkujących daną gminę. Wójt jako jednostka wykonawcza wykonuje uchwały rady gminy, przygotowuje projekty tychże uchwał wraz ze sposobami ich wykonania, reprezentuje gminę na zewnątrz, kieruje urzędem gminy, a także sprawuje funkcję kierownika urzędu stanu cywilnego. Ponadto wójt gospodaruje mieniem komunalnym, wykonuje budżet oraz przygotowuje jego projekt, sprawuje także zwierzchnictwo służbowe nad pracownikami urzędu gminy oraz wydaje decyzje administracyjne $w$ indywidualnych sprawach z zakresu administracji publicznej ${ }^{23}$.

Gmina wykonuje zadania własne oraz zlecone przez administrację rządową. Działania własne gminy zostały wymienione w art. 7 ustawy o samorządzie gminnym. Obejmują one sprawy:

- „ładu przestrzennego, gospodarki nieruchomościami, ochrony środowiska i przyrody oraz gospodarki wodnej;

- gminnych dróg, ulic, mostów, placów oraz organizacji ruchu drogowego;

- wodociągów i zaopatrzenia w wodę, kanalizacji, usuwania i oczyszczania ścieków komunalnych, utrzymania czystości i porządku oraz urządzeń sanitarnych, wysypisk i unieszkodliwiania odpadów komunalnych, zaopatrzenia w energię elektryczną i cieplną oraz gaz;

- działalności w zakresie telekomunikacji;

- lokalnego transportu zbiorowego;

- ochrony zdrowia;

- pomocy społecznej, w tym ośrodków i zakładów opiekuńczych;

- wspierania rodziny i systemu pieczy zastępczej;

- gminnego budownictwa mieszkaniowego;

- edukacji publicznej;

- kultury, w tym bibliotek gminnych i innych instytucji kultury oraz ochrony zabytków i opieki nad zabytkami;

- kultury fizycznej i turystyki, w tym terenów rekreacyjnych i urządzeń sportowych;

- targowisk i hal targowych;

- zieleni gminnej i zadrzewień;

- cmentarzy gminnych;

\footnotetext{
${ }^{22}$ Vide: B. Dolnicki, Samorzad terytorialny, Warszawa 2016, s. 77.

${ }^{23}$ Vide: J. Wyporska, Związki, porozumienia i stowarzyszenia samorządu terytorialnego, [w:] red. J.P. Tarno, Samorząd terytorialny w Polsce, Warszawa 2004, s. 154-155.
} 
- porządku publicznego i bezpieczeństwa obywateli oraz ochrony przeciwpożarowej i przeciwpowodziowej, w tym wyposażenia i utrzymania gminnego magazynu przeciwpowodziowego;

- utrzymania gminnych obiektów i urządzeń użyteczności publicznej oraz obiektów administracyjnych;

- polityki prorodzinnej, w tym zapewnienia kobietom w ciąży opieki socjalnej, medycznej i prawnej;

- wspierania i upowszechniania idei samorządowej, w tym tworzenia warunków do działania i rozwoju jednostek pomocniczych i wdrażania programów pobudzania aktywności obywatelskiej

- promocji gminy;

- współpracy i działalności na rzecz organizacji pozarządowych (...);

- współpracy ze społecznościami lokalnymi i regionalnymi innych państw"24.

Zgodnie z ustawą o samorządzie powiatowym organami powiatu są rada powiatu oraz zarząd powiatu ${ }^{25}$. Rada jest organem stanowiącym i kontrolnym, a radni wybierani są w wyborach bezpośrednich. Liczba radnych w powiatach wacha się od 19 do 29 osób w zależności od wielkości powiatu. Kadencja rady trwa 5 lat $^{26}$. Zarząd powiatu jest natomiast organem wykonawczym. Składa się on ze starosty, jego zastępców oraz pozostałych członków. Starosta i jego zastępcy wybierani są przez radę powiatu w głosowaniu tajnym bezwzględną większością głosów ustawowego składu rady ${ }^{27}$.

Powiat, podobnie jak gmina, wykonuje zadania własne w zakresie:

- ,edukacji publicznej;

- promocji i ochrony zdrowia

- pomocy społecznej;

- wspierania rodziny i systemu pieczy zastępczej;

- polityki prorodzinnej;

- wspierania osób niepełnosprawnych;

- transportu zbiorowego i dróg publicznych;

- kultury oraz ochrony zabytków i opieki nad zabytkami;

- kultury fizycznej i turystyki;

- geodezji, kartografii i katastru;

- gospodarki nieruchomościami;

- administracji architektoniczno-budowlanej;

- gospodarki wodnej;

\footnotetext{
${ }^{24}$ Ustawa z dnia 8 marca 1990 roku o samorządzie gminnym (Dz. U. $1990 \mathrm{Nr} 16$ poz. 95), art. 7.

${ }^{25}$ Vide: Ustawa z dnia 5 czerwca 1998 roku o samorządzie powiatowym (Dz. U. $1998 \mathrm{Nr} 91$ poz. 578) (Ustawa o samorządzie powiatowym), art. 8.

${ }^{26}$ Vide: Ibidem, art. 9.

${ }^{27}$ Vide: Ibidem, art. 26-27.
} 
- ochrony środowiska i przyrody;

- rolnictwa, leśnictwa i rybactwa śródlądowego;

- porządku publicznego i bezpieczeństwa obywateli;

- ochrony przeciwpowodziowej, w tym wyposażenia i utrzymania powiatowego magazynu przeciwpowodziowego, przeciwpożarowej i zapobiegania innym nadzwyczajnym zagrożeniom życia i zdrowia ludzi oraz środowiska;

- przeciwdziałania bezrobociu oraz aktywizacji lokalnego rynku pracy;

- ochrony praw konsumenta;

- utrzymania powiatowych obiektów i urządzeń użyteczności publicznej oraz obiektów administracyjnych;

- obronności;

- promocji powiatu;

- współpracy i działalności na rzecz organizacji pozarządowych (...);

- działalności w zakresie telekomunikacji”28.

Należy zaznaczyć, że zadania wykonywane przez powiat nie mogą naruszać zakresu działania gminy ${ }^{29}$. Ponadto, powiat może przekazać swoje zadania zainteresowanej gminie na zasadzie porozumienia ${ }^{30}$.

W przypadku województwa organami są sejmik wojewódzki i zarząd województwa ${ }^{31}$. Sejmik wojewódzki jest analogicznie organem stanowiącym i kontrolnym wybieranym w wyborach bezpośrednich w liczbie 30 osób w województwach do 2 mln mieszkańców oraz po trzech radnych na każde kolejne rozpoczęte 500 tys. mieszkańców. Kadencja sejmiku trwa 5 lat ${ }^{32}$. Organem wykonawczym jest zarząd województwa, w skład którego wchodzą marszałek województwa, jego zastępcy oraz pozostali członkowie. Zarząd województwa wybierany jest przez sejmik województwa ${ }^{33}$.

Zadania własne samorządy województwa dotyczą:

- „edukacji publicznej, w tym szkolnictwa wyższego;

- promocji i ochrony zdrowia;

- kultury oraz ochrony zabytków i opieki nad zabytkami;

- pomocy społecznej;

- wspierania rodziny i systemu pieczy zastępczej;

- polityki prorodzinnej;

- modernizacji terenów wiejskich;

\footnotetext{
${ }^{28}$ Ibidem, art. 4 ust. 1.

${ }^{29}$ Vide: Ibidem, art. 4 ust. 6.

${ }^{30}$ Vide: Ibidem, art. 4 ust. 5.

${ }^{31}$ Vide: Ustawa z dnia 5 czerwca 1998 roku o samorządzie województwa (Dz. U. 1998 Nr 91 poz. 576) (Ustawa o samorządzie województwa), art. 15.

${ }^{32}$ Vide: Ibidem, art. 16.

${ }^{33}$ Vide: Ibidem, art. 31-32.
} 
- zagospodarowania przestrzennego;

- ochrony środowiska;

- transportu zbiorowego i dróg publicznych;

- kultury fizycznej i turystyki;

- ochrony praw konsumentów;

- obronności;

- bezpieczeństwa publicznego;

- przeciwdziałania bezrobociu i aktywizacji lokalnego rynku pracy;

- działalności w zakresie telekomunikacji;

- ochrony roszczeń pracowniczych w razie niewypłacalności pracodawcy"34.

Należy zwrócić uwagę, że poszczególne jednostki samorządu terytorialnego (gmina, powiat i województwo) są od siebie niezależne. Nie mamy tu do czynienia z jakąkolwiek formą zwierzchnictwa. Jednostki te mają się uzupełniać po to, aby spełniać potrzeby mieszkańców. Organem nadzoru nad działalnością jednostek samorządu terytorialnego i ich związków pod względem legalności jest wojewoda jako przedstawiciel Rady Ministrów w województwie ${ }^{35}$. Należy zaznaczyć, że nie może on wpływać na działalność organów samorządu terytorialnego. „Nadzór nad samorządem terytorialnym tak naprawdę jest zdeterminowany wyłącznie rażącym naruszeniem prawa, w przypadku nieistotnego charakteru naruszenia wojewoda nie stwierdza nieważności badanych przepisów"36.

Administracja terenowa ma kluczowe znaczenie dla przebiegu szeregu procesów gospodarczych oraz społecznych. „Organy administracji samorządowej odgrywają znaczącą i pozytywną rolę w systemie organów władzy publicznej. Przede wszystkim jest to rola społeczna, która polega na oddaniu administracji publicznej w ręce grup społecznych. Wzmacnia to instytucje demokratyczne państwa i stwarza dla obywateli możliwość rzeczywistego wpływu na bieg spraw publicznych. Z punktu widzenia poziomu samej administracji publicznej niewątpliwą korzyścią, wynikającą z rozwiązań samorządowych, jest zapobieganie zbiurokratyzowaniu tej administracji, poddaniu jej bliższej kontroli społecznej, a także wzmocnienie jej skuteczności przez dostosowanie jej do rzeczywistych potrzeb środowisk ludzkich" ${ }^{\prime 3}$.

Zadania obronne realizowane są przez samorządy terytorialne w ramach niemilitarnych struktur Systemu Obronnego Państwa.

\footnotetext{
${ }^{34}$ Ibidem, art. 14 ust. 1.

${ }^{35}$ Vide: Ustawa z dnia 23 stycznia 2009r.o wojewodzie i administracji rządowej w województwie (Dz. U. 2009 Nr 31 poz. 206), art..3.

${ }^{36}$ M. Karpiuk, M. Czuryk, Zakres nadzoru wojewody nad działalnościa samorządu terytorialnego, „,Kwartalnik Prawa Publicznego" 7/4, 2007, s. 180-181.

${ }^{37}$ M. Kuliczkowski, Pozamilitarne przygotowanie obronne..., s. 97; Vide: J. Zimmermann, Prawo administracyjne, Warszawa 2010, s. 104.
} 


\section{ZADANIA OBRONNE SAMORZĄDÓW TERYTORIALNYCH}

Zadania obronne realizowane przez samorządy terytorialne można podzielić na trzy grupy (ochrona ludności i struktur państwowych, zapewnienie informacyjnych, duchowych i materialnych podstaw egzystencji ludności, uzupełnienie zasobami ludzkimi sił zbrojnych oraz cywilne wsparcie wojsk $)^{38}$, co zostało przedstawione w tabeli 1 . „Główne zadania obronne samorządów terytorialnych dotyczą: organizowania cywilno-gospodarczego wsparcia układu militarnego zgodnie z potrzebami sił zbrojnych własnych i sojuszniczych oraz zapewnienia ochrony ludności, a także porządku publicznego na administrowanym terenie, poprzez wszystkie możliwe do wykorzystania siły i środki wspólnoty terytorialnej z uwzględnieniem ścisłego współdziałania między organami administracji publicznej wszystkich szczebli" ${ }^{39}$.

\begin{tabular}{|c|c|c|}
\hline Grupa I & Grupa II & Grupa III \\
\hline $\begin{array}{l}\text { Ochrona ludności i struktur państwowych } \\
\text { w warunkach wewnętrznego i } \\
\text { zewnętrznego zagrożenia bezpieczeństwa } \\
\text { państwa, kryzysu polityczno-militarnego } \\
\text { i wojny }\end{array}$ & $\begin{array}{l}\text { Zapewnienie: } \\
-\quad \underline{\text { informacyjnych. }} \\
-\quad \underline{\text { duchowychi }} \\
\text { - } \underline{\text { materialnych }} \\
\text { podstaw egzystencji ludności w } \\
\text { warunkach wewnętrznego i } \\
\text { zewnętrznego zagrożenia bezpieczeństwa } \\
\text { państwa, kryzysu polityczno-militarnego } \\
\text { i wojny }\end{array}$ & $\begin{array}{l}\frac{\text { Uzupelnienie zasobami ludzkimi sil }}{\text { zbrojnych oraz cywilne wsparcie wojsk }} \\
\text { wlasnych i sojuszniczych prowadzących } \\
\text { operacje na terytorium państwa }\end{array}$ \\
\hline
\end{tabular}

Tabela 2. Trzy grupy zadań obronnych realizowanych przez samorządy terytorialne

Źródło: opracowanie własne na podstawie M. Kuliczkowski, Pozamilitarne przygotowanie obronne ..., op. cit., s. 133.

Gmina w zakresie obronności realizuje działania związane z powszechnym obowiązkiem obrony, a także współdziała $\mathrm{z}$ organami wojskowymi w sferze administrowania rezerwami osobowymi. Prowadzi również rejestrację na potrzeby ewidencji wojskowej oraz kwalifikację wojskową osób objętych rejestracją. Ponadto prowadzi sprawy związane z wojskowym obowiązkiem meldunkowym oraz umieszcza obwieszczenia o powołaniu osób do czynnej służby wojskowej, a także organizuje system doręczania kart powołania (w ramach akcji kurierskiej) do odbycia ćwiczeń wojskowych przeprowadzanych w trybie natychmiastowego stawiennictwa oraz do czynnej służby wojskowej pełnionej w razie ogłoszenia mobilizacji i w czasie wojny ${ }^{40}$.

Wójt, burmistrz czy prezydent miasta opracowują plan akcji kurierskiej w zakresie rejonów i tras bezpośredniego doręczenia kart powołania adresatom ${ }^{41}$.

Po stronie gminy leży także wydawanie decyzji w sprawie przeznaczenia osób do funkcji kuriera. Poza tym, gmina planuje świadczenia osobiste i rzeczowe na okres pokoju

\footnotetext{
${ }^{38}$ Vide: M. Kuliczkowski, Pozamilitarne przygotowanie obronne..., op. cit., s. 133.

${ }^{39}$ Ibidem, s. 133-134.

${ }^{40}$ Vide: Ibidem, s. 135.

${ }^{41}$ Vide: R. Dynak, Uwarunkowania realizacji zadań obronnych przez samorzady terytorialne na poszczególnych szczeblach organizacyjnych, [w:] red. W. Kitler, Samorząd terytorialny w obronie narodowej Rzeczypospolitej Polskiej, Warszawa 2005, s. 156.
} 
i wojny oraz wydaje decyzje administracyjne o nałożeniu obowiązku świadczeń, jak również wzywa do ich wykonania. Co więcej, prowadzi ewidencję rzeczy ruchomych i nieruchomości, które mogą stać się przydanym świadczeniem rzeczowym, oraz udziela informacji o ich stanie na żądanie wojskowych komendantów uzupełnień czy innych właściwych organów obrony cywilnej $^{42}$. W razie wojny gmina zobowiązana jest do przystosowania i udostępnienia nieruchomości i rzeczy ruchowych na potrzeby obronne. Gmina ma również prawo do ograniczenia „obowiązku przewozu” w stosunku do transportu gminnego ze względu na potrzeby obronności. Wójt, burmistrz lub prezydent miasta mają prawo nałożyć na obywateli obowiązki w ramach przygotowania osób i mienia, infrastruktury technicznej i gospodarczej własnych ujęć wody pitnej i środków spożywczych, utrzymania indywidualnych środków ochrony oraz pomieszczeń ochronnych oraz innych przedsięwzięć mających na celu ochronę własnego życia, zdrowia i mienia oraz udzielenia pomocy poszkodowanym ${ }^{43}$.

Powiat również zobowiązany jest do przeprowadzania czynności związanych z wykonywaniem powszechnego obowiązku obrony, w tym do współpracy z organami administrowania rezerwami osobowymi. Powiat współdziała również w organizowaniu i przeprowadzeniu kwalifikacji wojskowej poprzez zabezpieczenie pomieszczeń i dokumentacji. Bierze także udział w ramach akcji kurierskiej w organizacji systemu doręczania kart powołania do odbycia ćwiczeń wojskowych ${ }^{44}$. Ponadto powiat tworzy i utrzymuje zasoby geodezyjne na potrzeby obronne, a także opiniuje wykaz dróg o znaczeniu obronnym oraz ich przebieg w ramach powiatu ${ }^{45}$.

Województwo również przeprowadza czynności związane z wykonywaniem powszechnego obowiązku obrony, w tym współpracuje z organami administrowania rezerwami osobowymi ${ }^{46}$. Poza tym zadania obronne województwa sprowadzają się przede wszystkim do opiniowania przebiegu dróg o znaczeniu obronnym zaliczonych do dróg wojewódzkich oraz tworzenia i utrzymania zasobów geodezyjnych i kartograficznych na potrzeby obronne ${ }^{47}$.

Należy zaznaczyć, że samorządy terytorialne realizują przedsięwzięcia wynikające z poszczególnych stanów gotowości. W aspekcie organizacyjnym gminy i powiaty poprzez odpowiednio gminne i powiatowe centra reagowania tworzą systemy stałych dyżurów (na podstawie zarządzenia właściwego wojewody), które będą organizowane na potrzeby ciągłości przekazywania decyzji organów uprawnionych do uruchamiania realizacji zadań przyjętych w Planie reagowania obronnego RP. Opracowują również regulaminy organizacyjne i planują obsadę etatową urzędów na czas wojny ${ }^{48}$.

Analizując zadania obronne realizowane przez samorządy terytorialne, bazując na kryterium rodzaju, należy stwierdzić, że w obszarze zadań o charakterze przygotowawczym

\footnotetext{
${ }^{42}$ Vide: M. Kuliczkowski, Pozamilitarne przygotowanie obronne..., op. cit., s. 134-135.

${ }^{43}$ Vide: R. Dynak, Uwarunkowania realizacji zadań obronnych ..., op. cit., s. 145-146.

${ }^{44}$ Vide: M. Kuliczkowski, Pozamilitarne przygotowanie obronne..., op. cit., s. 134-135.

${ }^{45}$ Vide: R. Dynak, Uwarunkowania realizacji zadań obronnych..., op. cit., s. 146.

${ }^{46}$ Vide: M. Kuliczkowski, Pozamilitarne przygotowanie obronne ..., op. cit., s. 134.

${ }^{47}$ Vide: R. Dynak, Uwarunkowania realizacji zadań obronnych..., op. cit., s. 146.

${ }^{48}$ Vide: Ibidem, s. 151-152.
} 
samorządy terytorialne organizują stanowiska kierowania, mają swój udział w planowaniu obronnym przez tworzenie planów operacyjnych, mają wpływ na edukację obronną (edukacja publiczna leży w kompetencjach samorządu terytorialnego wszystkich szczebli), mają udział w szkoleniach obronnych. Do zadań gospodarczo-obronnych realizowanych przez samorządy terytorialne zaliczyć można zapewnienie podstaw do realizacji zadań obronnych (m.in. tworzenie podstaw funkcjonowania stanowisk kierowania), przygotowanie dróg na potrzeby obronne, uruchomienie świadczeń osobistych i rzeczowych, wprowadzenie ograniczeń w komunikacji, zapewnienie zaopatrzenia formacji obrony cywilnej w sprzęt, materiały i środki ochronne. Samorząd wykonuje także szereg zadań ochronnych zarówno tych związanych z zapewnieniem sprawnego funkcjonowania państwa (m.in. zapewnienie łączności, ochrona dóbr kultury i dziedzictwa narodowego, zapewnienie bezpieczeństwa i porządku publicznego, ochrona obiektów szczególnie ważnych, w tym obiektów infrastruktury krytycznej, co zostało ujęte w Narodowym Programie Ochrony Infrastruktury Krytycznej), jak i zapewnieniem potrzeb bytowych ludności (ochronę poprzez zapewnienie przetrwania ludności cywilnej przed niebezpieczeństwami spowodowanymi siłami natury i działalnością człowieka).

Zadania obronne realizowane przez samorządy terytorialne mieszczą się w obszarze pozamilitarnych przygotowań obronnych. Poniżej dokonano próby identyfikacji zakresu przedmiotowego zadań obronnych realizowanych przez samorządy.

W ramach planowania operacyjnego na każdym szczeblu opracowywane są plany operacyjne funkcjonowania odpowiednio gminy, powiatu i województwa. Opracowują je właściwi miejscowo wójtowie, burmistrzowie, prezydenci miasta, starostowie i marszałkowie województwa w uzgodnieniu z wojewodą ${ }^{49}$.

Samorządy terytorialne przygotowują na własne potrzeby główne stanowiska kierowania $\mathrm{W}$ swojej siedzibie oraz $\mathrm{w}$ zapasowym miejscu pracy, które uzgadnia się z właściwym wojewodą. Przygotowanie stanowiska kierowania wiąże się z:

- opracowaniem dokumentacji związanej z przemieszczeniem i zapewnieniem warunków funkcjonowania organu na stanowisku kierowania;

- utrzymaniem stanu technicznego oraz modernizacją infrastruktury przez jej użytkowników w czasie pokoju;

- ustaleniem zasad i trybu obiegu informacji;

- wyposażeniem w urządzenia filtrowentylacyjne, źródła energii oraz ujęcia wody;

- wyposażeniem w urządzenia techniczne i sanitarne, sprzęt biurowy i kwaterunkowy niezbędny do pracy i odpoczynku;

- uodpornieniem na oddziaływanie środków poznania i rażenia przeciwnika (przez maskowanie i rozbudowę ukryć i schronów);

- zorganizowaniem zaopatrzenia: żywnościowego, medycznego, transportowego;

- zaopatrzeniem w materiały pędne;

\footnotetext{
${ }^{49}$ Vide: M. Kuliczkowski, Pozamilitarne przygotowanie obronne..., op. cit., s. 136.
} 
- zorganizowaniem systemu powiadamiania i alarmowania o zagrożeniu z powietrza oraz skażeniach i zakażeniach;

- przygotowaniem środków do rozwinięcia i odtwarzania systemów łączności i bezpieczeństwa teleinformatycznego;

- prowadzeniem akcji ratunkowych, ochrony stanowisk kierowania przed obezwładnieniem radioelektronicznym;

- $\quad$ szkoleniem pracowników zapewniających utrzymanie obiektów specjalnych stanowisk kierowania w gotowości do ich wykorzystania ${ }^{50}$.

Samorządy terytorialne utrzymują stałą gotowość obronną oraz tworzą warunki do jej podtrzymania poprzez wykonywanie określonych zadań obronnych w systemie stałych dyżurów ${ }^{51}$.

Władze samorządów terytorialnych na każdym szczeblu zobowiązane są do realizacji zadań dotyczących przygotowania dróg odpowiednio gminnych, powiatowych i wojewódzkich na potrzeby obronne (drogi te zostały wskazane w wykazie dróg o znaczeniu obronnym) ${ }^{52}$.

Podmioty wykonawcze (odpowiednio: wójt/burmistrz, prezydent miasta/starosta, marszałek województwa) przygotowują i wykorzystują podmioty lecznicze na potrzeby obronne ${ }^{53}$. Wśród zadań należy wymienić:

- planowanie i realizacja zadań w zakresie:

- zwiększenia liczby łóżek bazy szpitalnej i zmiany jej profilu,

- tworzenia zastępczych miejsc szpitalnych,

- wykonywania ambulatoryjnych świadczeń zdrowotnych,

- określenia sposobu zabezpieczenia potrzeb kadrowych oraz wskaźników zatrudnienia w podmiotach leczniczych,

- wykorzystania jednostek organizacyjnych publicznej służby krwi,

- określenia sposobu zabezpieczenia sanitarno-epidemiologicznego,

- określenia sposobu postępowania w przypadku wystąpienia zdarzenia radiacyjnego,

- określenia sposobu realizacji świadczeń na potrzeby jednostek podległych lub nadzorowanych przez Ministra Obrony Narodowej i ministra właściwego do spraw wewnętrznych oraz na potrzeby Szefa Agencji Bezpieczeństwa Wewnętrznego,

- określenie sposobu i zakresu prowadzenia ewidencji i sprawozdawczości medycznej w warunkach masowego napływu poszkodowanych, rannych i chorych,

- określenie sposobu realizacji świadczeń na rzecz podmiotów leczniczych realizujących zadania obronne;

\footnotetext{
${ }^{50}$ Vide: Rozporządzenie Rady Ministrów z dnia 27 kwietnia 2004 r. w sprawie przygotowania systemu kierowania bezpieczeństwem narodowym (Dz. U. 2004 nr 98 poz. 978), § 16.

${ }^{51}$ Vide: M. Kuliczkowski, Pozamilitarne przygotowanie obronne..., op. cit., s. 137.

52 Vide: Ustawa z dnia 21 marca 2005 r. o drogach publicznych (Dz. U. 2004, nr 204, poz. 2086 z późn. zm.), art. $4 a$ ust.2.

${ }^{53}$ Vide: M. Kuliczkowski, Pozamilitarne przygotowanie obronne..., op. cit., s. 137-138.
} 
- $\quad$ koordynowanie planowania i realizacji wyżej wymienionych zadań ${ }^{54}$.

Ponadto poszczególne szczeble samorządu terytorialnego zobowiązane są do przygotowania i wykorzystania systemów łączności na potrzeby obronne. Samorządy uwzględniają potrzeby wynikające z zapewnienia bezpieczeństwa państwa przy planowaniu, budowie, rozbudowie, eksploatacji lub łączeniu systemów łączności oraz zaspokajają potrzeby dotyczące funkcjonowania obronnych systemów łączności w szczególności na stanowiskach kierowania ${ }^{55}$.

W ramach przygotowania do prowadzenia szczególnej ochrony obiektów samorządy organizują szczególną ochronę obiektów znajdujących się na terenie gminy/ powiatu/województwa oraz wyznaczają osoby odpowiedzialne za realizację ochrony ${ }^{56}$.

Należy nadmienić, że „organy samorządów wszystkich szczebli są zobowiązane do: udziału w szkoleniach obronnych prowadzonych przez jednostki nadrzędne; organizowania i prowadzenia szkoleń obronnych na administrowanym terenie; opracowania i uzgadniania szkoleń obronnych z wojewodą; typowania osób do przeszkolenia; zapewnienia właściwych warunków i środków finansowych do realizacji procesu szkolenia z wyjątkiem kosztów szkolenia dla wójtów, starostów, marszałków, które ponosi wojewoda" ${ }^{27}$.

Samorządy terytorialne dokonują także kontroli zadań obronnych w stosunku do urzędów gmin, starostw powiatowych i urzędów marszałków województw oraz jednostek organizacyjnych, dla których organ samorządu terytorialnego jest organem założycielskim. Zakres kontroli obejmuje wykonywanie zadań obronnych wynikających z przepisów prawnych. Organy samorządów terytorialnych planują i zarządzają przeprowadzeniem kontroli problemowych i doraźnych odpowiednio do zakresu swojej właściwości, natomiast wojewoda koordynuje działalność samorządów terytorialnych w zakresie kontroli problemowej ${ }^{58}$. Choć wyższe szczeble samorządu terytorialnego nie mają uprawnień nadrzędnych i nadzorczych w stosunku do szczebli niższych, to w tworzeniu wzajemnych zależności dotyczących wykonywania zadań obronnych nie może obyć się bez hierarchicznego podporządkowania i wspierania poszczególnych szczebli samorządu terytorialnego w spełnieniu celu nadrzędnego - zapewnieniu bezpieczeństwa ${ }^{59}$.

Należy pamiętać, że wszystkie zadania w sferze obronności realizowane przez poszczególne szczeble samorządu terytorialnego wynikają z aktów prawnych. Sprawowaniem pieczy nad ich realizacją, a zatem koordynowaniem i kierowaniem zajmuje się właściwy miejscowo wojewoda.

\footnotetext{
${ }^{54}$ Vide: Rozporządzenie Rady Ministrów z dnia 27 czerwca 2012 r. w sprawie warunków i sposobu przygotowania oraz wykorzystania podmiotów leczniczych na potrzeby obronne państwa oraz właściwości organów w tych sprawach (Dz. U. 2012 poz. 741), § 1. 1.

${ }^{55}$ Vide: M. Kuliczkowski, Pozamilitarne przygotowanie obronne..., op. cit., s. 138.

${ }^{56}$ Vide: Ibidem, s. 139.

${ }^{57}$ R. Dynak, Uwarunkowania realizacji zadań obronnych..., op. cit., s. 135.

${ }^{58}$ Vide: M. Kuliczkowski, Pozamilitarne przygotowanie obronne..., op. cit., s. 139-140.

${ }^{59}$ Vide: R. Dynak, Uwarunkowania realizacji zadań obronnych..., op. cit., s. 135.
} 


\section{PodsumoWANie}

Celem artykułu była próba identyfikacji zadań obronnych wykonywanych na poszczególnych szczeblach samorządu terytorialnego. Realizacja przyjętego zamiaru wiązała się z rozwiązaniem problemu badawczego sformułowanego w postaci pytania: Jakie zadania obronne realizują samorządy terytorialne w Polsce? Podejmując próbę rozwiązania problemu należy wyjść od przyznania, że samorządy terytorialne odgrywają niezwykle istotą rolę w systemie organów władzy. Jest to rola przede wszystkim społeczna, gdyż podkreśla demokratyczny ustrój państwa i oddanie władzy w ręce grup społecznych.

Poszczególne szczeble samorządu terytorialnego zobowiązane są do wykonywania wielu zadań, w tym zadań obronnych. Na wszystkich szczeblach samorządu terytorialnego istotne i obligatoryjne jest planowanie oraz świadczenie osobistych i rzeczowych świadczeń na rzecz obronności w czasie pokoju, kryzysu i wojny.

Gmina w zakresie obronności realizuje takie działania jak $\mathrm{m}$ in.: administrowanie rezerwami osobowymi, rejestracja na potrzeby ewidencji wojskowej, obwieszczenie o powołaniu osób do czynnej służby wojskowej, organizacja systemu doręczania kart powołania do odbycia ćwiczeń wojskowych. Gmina wydaje także decyzje w sprawie przeznaczenia osób do funkcji kuriera, planuje świadczenia osobiste i rzeczowe na okres pokoju i wojny oraz wydaje decyzje administracyjne o nałożeniu obowiązku świadczeń i wzywa do ich wykonania, a także prowadzi ewidencję rzeczy ruchomych i nieruchomości przydatnych dla obronności.

Powiat również prowadzi czynności związane z wykonywaniem powszechnego obowiązku obrony, współdziała w organizowaniu i przeprowadzeniu kwalifikacji wojskowej poprzez zabezpieczenie pomieszczeń i dokumentacji, ma też udział w akcji kurierskiej oraz tworzy i utrzymuje zasoby geodezyjne na potrzeby obronne, a także opiniuje wykaz dróg o znaczeniu obronnym oraz ich przebieg $w$ ramach powiatu.

Zadania obronne województwa, obok przeprowadzania czynności związanych z wykonywaniem powszechnego obowiązku obrony, obejmują m. in. opiniowanie przebiegu dróg wojewódzkich o znaczeniu obronnym oraz tworzenie i utrzymanie zasobów geodezyjnych i kartograficznych na potrzeby obronne.

Samorządy terytorialne realizują zadania $\mathrm{z}$ zakresu planowania obronnego poprzez opracowanie planów operacyjnych funkcjonowania odpowiednio gmin, powiatów i województw. Ponadto są zobowiązane do przygotowywania stanowisk kierowania organów wykonawczych samorządu, z czym wiąże się szereg innych przedsięwzięć. Co więcej, samorządy zobligowane są do utrzymania stałej gotowości obronnej oraz tworzenia warunków do jej podtrzymania, a także przygotowania i wykorzystania podmiotów leczniczych, systemów łączności, dróg i transportu na potrzeby obronne. Zajmują się również szczegółową ochroną obiektów znajdujących się na administrowanym terenie. Wykonują też szereg zadań związanych z szkoleniami obronnymi. Ponadto, mają udział w kontroli wykonywania zadań obronnych. 


\section{BIBLIOGRAFIA}

(Mini)Słownik BBN. https://www.bbn.gov.pl/pl/bezpieczenstwo-narodowe/minislownik-bbnpropozy/6035,MINISLOWNIK-BBN-Propozycje-nowych-terminow-z-dziedzinybezpieczenstwa.html (dostęp: 27.05.2019)

Biała Księga Bezpieczeństwa Narodowego Rzeczypospolitej Polskiej. 2013. Warszawa Byjoch Krzysztof, Sulimierski Jerzy, Tarno Jan Paweł. 2000. Samorząd terytorialny po reformie ustrojowej państwa. Warszawa: Wydawnictwa Prawnicze PWN.

Dolnicki Bogdan. 2016. Samorząd terytorialny. Warszawa: Wolters Kluwer.

Dynak Robert. 2005. Uwarunkowania realizacji zadań obronnych przez samorządy terytorialne na poszczególnych szczeblach organizacyjnych. W Samorząd terytorialny w obronie narodowej Rzeczypospolitej Polskiej, 93-182. AON.

Karpiuk Mirosław, Czuryk Małgorzata. 2007. Zakres nadzoru wojewody nad działalnością samorządu terytorialnego. „Kwartalnik Prawa Publicznego” Tom 7 (Nr 4): 179-195.

Kitler Waldemar. 2006. Zadania obronne samorządu terytorialnego w świetle obowiązujących przepisów prawnych. W Zadania obronne samorządu terytorialnego: materiał studyjny, 12-69. AON.

Kuliczkowski Marian. 2011. Przygotowanie obronne państwa w systemie bezpieczeństwa narodowego - wybrane problemy. W Administracja publiczna i przedsiębiorcy w obszarze pozamilitarnych przygotowań obronnych państwa. Wybrane zagadnienia teorii i praktyki, 10-45. AON.

Kuliczkowski Marian. 2016. Pozamilitarne przygotowanie obronne w Polsce: próba systematyzacji procesualnych oraz funkcjonalnych aspektów przygotowań. Warszawa: AON.

Rozporządzenie Rady Ministrów z dnia 27 czerwca 2012 r. w sprawie warunków i sposobu przygotowania oraz wykorzystania podmiotów leczniczych na potrzeby obronne państwa oraz właściwości organów w tych sprawach (Dz. U. 2012 poz. 741)

Rozporządzenie Rady Ministrów z dnia 27 kwietnia 2004 r. w sprawie przygotowania systemu kierowania bezpieczeństwem narodowym (Dz. U. 2004 nr 98 poz. 978)

Ustawa z dnia 21 marca 2005 r. o drogach publicznych (Dz. U. 2004, nr 204, poz. 2086 z późn. zm.) Ustawa z dnia 23 stycznia 2009r.o wojewodzie i administracji rządowej w województwie (Dz. U. $2009 \mathrm{Nr} 31$ poz. 206).

Ustawa z dnia 5 czerwca 1998 roku o samorządzie powiatowym (Dz. U. $1998 \mathrm{Nr} 91$ poz. 578). Ustawa z dnia 5 czerwca 1998 roku o samorządzie województwa (Dz. U. 1998 Nr 91 poz. 576). Ustawa z dnia 8 marca 1990 roku o samorządzie gminnym (Dz. U. $1990 \mathrm{Nr} 16$ poz. 95).

Wyporska Joanna. 2004. Związki, porozumienia i stowarzyszenia samorządu terytorialnego.

W Samorząd terytorialny w Polsce, 156-170, Wydawnictwo Prawnicze Lexis Nexis.

Zimmermann Jan. 2010. Prawo administracyjne. Warszawa: Wydawnictwo Oficyna. 